\title{
Viking Age
}

\section{Comments on the Development of Archaeology in Sweden from 1986 to 1990 based on "Nordic Archaeological Abstracts"}

\author{
Ola Kyhlberg
}

\begin{abstract}
The development of Viking Age archaeology in Sweden is briefly discussed on the basis of a bibliographical and statistical study of the period from 1986 to 1990 . The study reveals that Swedish archaeology has undergone two separate and now concluded "waves of evolution" during the twentieth century. The current tradition can be traced back to the 1970s. The developement can be described as that of a longue durée including some very swift changes (events), especially around $1987 / 88$. This hermeneutic spiral seems to move from the artefacts to the contexts.
\end{abstract}

Ola Kyhlberg, The Central Board of National Antiquities, S-114 84 Stockholm, Sweden.

As the heading indicates, this paper does not have the pretensions of totally covering $\mathrm{Vi}$ king Age research and publications between 1986 and 1990. It must be emphasized that the author himself is dependent on a certain tradition of research and is not an objective observer. The aim of the presentation is therefore to give an overall picture of the development of some major events and publications.

This contribution has a quantitative as well as a qualitative approach. The quantitative part sets out from a study of the doctoral theses published in the Nordic countries during the twentieth century. The results from this have been applied to the bibliographical information in the issues of NAA from 1986 to 1990 . The object of this has been to try to get a reference for the ordinary qualitative discussion.

The history of archaeological science has been penetrated and discussed by a number of authors on several occasions. The studies have been predominantly biographical and qualitative, focusing on the history of individuals. Rather in this spirit Hyenstraid has presented an explicatory model made up of periods of c. 30 years each and beginning with the year of the thesis by Oscar Almgren (1897) (Hyenstrand 1988:11 f). The first period, c. 1897 - 1927, is characterized by Hyenstrand as a phase of consolidation. Big projects were initiated and regional/chronological surveys were presented. During this period there existed a distinct interest in the old written sources. The second period, c. 1927 - 1957, was the main period for the study of style and ornamental art, but also the period when the settlement archaeology appeared. The subsequent period, c. 1957 1987, was the most dynamic one, according to Hyenstrand. The period can be said to have been dominated by Mats P. Malmer, whose production represented a first step away from the empirical and traditionalistic research. This is the period when archaeo- 
logy opened up to other sciences, such as osteology or cultural geography, and when modern settlement archaeology was introduced by Björn Ambrosiani in his thesis Fornlämningar och bebyggelse (Stockholm 1964). According to Hyenstrand the present situation is characterized by a certain tendency towards the empirical basis.

Modern archaeology and the different theoretical doctrines have been mapped and described thoroughly by Ronnie Jensen (1988). As a theoretical reference for the bibliographical account given below, this article is recommended.

The qualitative approach to the question of the development of archaeology in the twentieth century can preferably be tested and completed with a quantitative analysis. As will be shown, this leads to a reassessment of the linear and qualitative processual model which is then replaced by a quantitative and cyclic model, as hinted at by Hyenstrand.

\section{IN SEARCH OF TRENDS. THE DOCTORAL THESES 1897 - c. 1980.}

In a bibliographical analysis of the doctoral theses in the Nordic countries from 1897 to c. 1980 the development was mapped by means of a seriation matrix (Kyhlberg 1982). The two variables combined were on the one hand the chronological period of publication, and on the other hand nine classificatory categories. These categories were all defined for operational reasons, and not on a strict bibliographical basis. Consequently the results were presented on a rather generalized level. The seriation matrix is reproduced here, with some modifications in Tab. 1.

The technique and its underlying methodology will be briefly described here. A frequency table was constructed, based on the counted and added codes. The figures/ observations were transformed into percentages for each row (five-year periods of publication). These values were weighted vertically by the mean, incl. $0 \%$ (for every category). The table was transformed into a seriation matrix by rearranging the columns/ categories. The chronology was of course fixed. After that the standard deviation was calculated for each column.

This semi-statistical method of seriation has previously been successfully tested in different connections.

In Tab. 1 the seriation matrix for the doctoral theses is in fact illustrating the genetics of the scientific development (cf. Jensen 1988). The seriation matrix shows typical signs of a cultural behaviour, a pattern wellknown from other contexts and a parallel to the descriptions of culture given by Kroeber (1919/1952) and by Braudel (1980:27 ff), where a cultural process has a long-term perspective (la longue durée) as well as a shorter perspective. So even the academic history of science appears to fit into this model; a dominating tradition consists of a number of shorter phases.

The seriation matrix reveals that this complex process has a cyclic, not a linear, development and is thereby a parallel to the hermeneutic spiral (cf. Jensen 1988:52). The first "wave" of development could be shown to comprise the period between c. 1900 and c. 1950 . The second "wave" comprised the period from c. 1935/40 to around 1980, and the third, now ongoing "wave" the years after c. 1970/75. This process of development can be said to have led from the empirical basis to the contextual approach, thereby elevating the level of interpretation. It could be noted that the point most remote from the beginning of the development is the category "techniques and technology" and the category "history of science and dataanalysis". As this is a question of a spiral movement, the situation is a logical one: from the survey to the details and from the technological aspect to the artefacts.

According to the seriation matrix in Tab. 1, during the twentieth century Swedish archaeology has undergone this cycle twice and has now entered the third "wave" 


\begin{tabular}{|c|c|c|c|c|c|c|c|c|c|}
\hline & & & & & & & & EGO & IES: \\
\hline & & 1 & 2 & $3 / 4$ & 5 & 6 & 7 & 8 & 9 \\
\hline & $7-1910$ & 19 & 31 & 44 & 0 & 6 & 0 & 0 & 0 \\
\hline & -1915 & 11 & 3 & 59 & 9 & 11 & 6 & 0 & 0 \\
\hline & -1920 & 0 & 40 & 60 & 0 & 0 & 0 & 0 & 0 \\
\hline & -1925 & 0 & 0 & 50 & 25 & 12 & 12 & 0 & 0 \\
\hline & -1930 & 0 & 20 & 60 & 0 & 20 & 0 & 0 & 0 \\
\hline & -1935 & 3 & 43 & 29 & 3 & 6 & 9 & 6 & 0 \\
\hline & -1940 & 14 & 29 & 36 & 7 & 0 & 7 & 7 & 0 \\
\hline & -1945 & 6 & 37 & 37 & 11 & 0 & 6 & 3 & 0 \\
\hline & -1950 & 0 & 26 & 67 & 0 & 0 & 6 & 0 & 0 \\
\hline & -1955 & 4 & 24 & 51 & 12 & 6 & 4 & 0 & 0 \\
\hline & -1960 & 0 & 25 & 59 & 17 & 0 & 0 & 0 & 0 \\
\hline & -1965 & 9 & 14 & 41 & 17 & 14 & 5 & 0 & 0 \\
\hline & -1970 & 5 & 24 & 43 & 5 & 9 & 9 & 5 & 0 \\
\hline YEARS OF & -1975 & 9 & 23 & 39 & 0 & 9 & 9 & 10 & 2 \\
\hline PUBLICATION & -1980 & 15 & 26 & 34 & 4 & 6 & 12 & 1 & 2 \\
\hline $\bar{x}($ & $=15)$ & 6.3 & 24.5 & 47.3 & 7.3 & 6.6 & 5.7 & 2.1 & 0.3 \\
\hline CATEGORIES: & & & & & & & & & \\
\hline 1. Single ancie & t monume & sites o & burial & grounds & & & & & \\
\hline 2. Surveys of a & cient mon & nts, ar & efact ty & pes or $q$ & oups. & & & & \\
\hline $3 / 4$. Surveys of $\mathrm{c}$ & ronologic & riods & $\mathrm{r}$ of cul & tural gr & ips. & & & & \\
\hline 5. Analyses of & tyle and or & ient. $\mathrm{F}$ & Inolog & and an & yses & writte & source & & \\
\hline 6. Settlement a & d cultural & scape & & & & & & & \\
\hline $\begin{array}{l}\text { 7. Economy, tr } \\
8\end{array}$ & de. Numis & $\mathrm{cs} . \mathrm{Cu}$ & tural ec & ntacts. & & & & & \\
\hline $\begin{array}{l}\text { 8. Techniques, } \\
\text { 9. History of }\end{array}$ & echnology & & & & & & & & \\
\hline
\end{tabular}

Tab. 1. The doctoral theses in the Nordic countries from 1897 to c. 1980. Seriation matrix based on the percentual distribution within every fifth-year period. The values are weighted vertically by the mean of every column. Values exeeding this mean are framed.

of development. This division into three traditions is also visible in categories $1,2,5$, 6 and 7.

To illustrate the semi-statistical or quantitative character of this seriation method we can take a closer look at the change of traditions in the 1930s. Evidently this took place when category 8 was introduced for the first time (i. e. "techniques and technology") as well as the contemporaneous theses belonging to category 1 (i. e. "single ancient monuments, sites or burial grounds").
The theses in question are those by Andreas Oldeberg (1933), Agnes Geijer (1938) and Axel Steensberg (1942), and those by Björn Hougen (1935), Oskar Lidén (1938) and Nils Cleve (1943) (Kyhlberg 1982).

The second change of traditions appears in the matrix with the new appearances within categories 1 and 2 from the 1960s onwards: Sverre Marstrander (1963), Ulf Erik Hagberg (1967), Jonas Ferenius (1971), Agneta Lundström (1971), Elisabeth Iregren (1972), Kjerstin Cullberg (1973) and Inga 
Hägg (1974) among others. The thesis by Berta Stjernquist (1955) appears in category 1 as a pioneer achievement, for a long time without successors (Kyhlberg 1982).

Another clearly visible feature is the relative homogeneity of the second tradition compared with the first one. The standard deviations can be used to test the originality of the category. A statistical spread below $100 \%$ is an indicator of stability and independence. This is valid for categories 2 , $3 / 4,6$ and 7 . For categories $1,5,8$ and 9 the statistical spread is more than $100 \%$. The series begins and ends with a category of this kind, i. e. probably of innovative character. But category 5 is characterized by the conspicuous anomaly in the chronological classes around 1930-45. This is due to the theses by Björn Hougen (1935), Wilhelm Holmqvist (1939), Greta Arwidsson (1942) and Ruben Gabrielsson (1945). Concerning category 6 ("settlement and cultural landscape") the first "wave" of tradition was concluded in 1933 with the thesis by Marten Stenberger, a major work generally considered to be of great importance to the researchers of the following generation. Björn Ambrosiani, the first of these researchers presented his thesis in 1964, initiating a strong academic tradition at Stockholm University.

\section{IN SEARCH OF TRENDS. "NAA" 1986 $-1990$.}

In the previous presentation the published theses were operationally codified. In searching for trends concerning modern publication, NAA and its codifications is a very useful tool for descriptive statistics of the kind discussed above. The method employed below will be the same with the exception that the codes are now taken directly from NAA, litt:s A - L. The experience of the analysis of the doctoral theses has been the basis for establishing the series of categories from NAA. The result of the seriation is presented in Tab. 2 and 3. The matrix estab- lished for the NAA material shows a very clear and easily understandable structure.

The development illustrated in Tab. 2 is that of longue durée but with some very swift changes from one year to another. It is also interesting to see the concentration of the 1986 production compared with the production of 1988 or the publications with Viking Age only as the secondary code, added below the main matrix. In Tab. 3 the information has been transformed into a series of headings/categories in analogy with the matrix of Tab. 2. "Historical, philological and numismatical sources" dominate strongly, followed by "artefacts etc., burial customs etc.", "rural settlements etc.", "theory etc.","'secular architecture etc.", "environment etc.", "urban settlement etc.", and "general etc.".

It can be noted that the arrangement of the columns is not only supported by the values exceeding the vertical mean but also by the numerical logic within the matrix, i.e. the existence of the so-called good curve. This postulate is also applicable to the series of values of the standard deviation.

The matrix shows that there was a drastic change from 1987 to 1988 . If the information of the matrix is translated, one can maintain that this was a transition from a traditionalistic and positivistic to a more contextual approach, a veritable change of paradigm. There are other signs of the same thing taken from outside the seriation matrix. Papers with a gender perspective are seven in 1986 and 1987, but 15 in 1988 and 1989. Other examples could be given to support this observation.

The precision of the method can be illustrated by the relative under-representation in category J for the last year, 1990. One of the papers reconsiders Bulverket on Gotland (NAA 1990:291), where the interpretation as a fortification is rejected. Thereby the article is not given the code $8 \mathrm{~J}$, but $8 \mathrm{D} 9 \mathrm{D}(89) \mathrm{E}$. But if the code is 


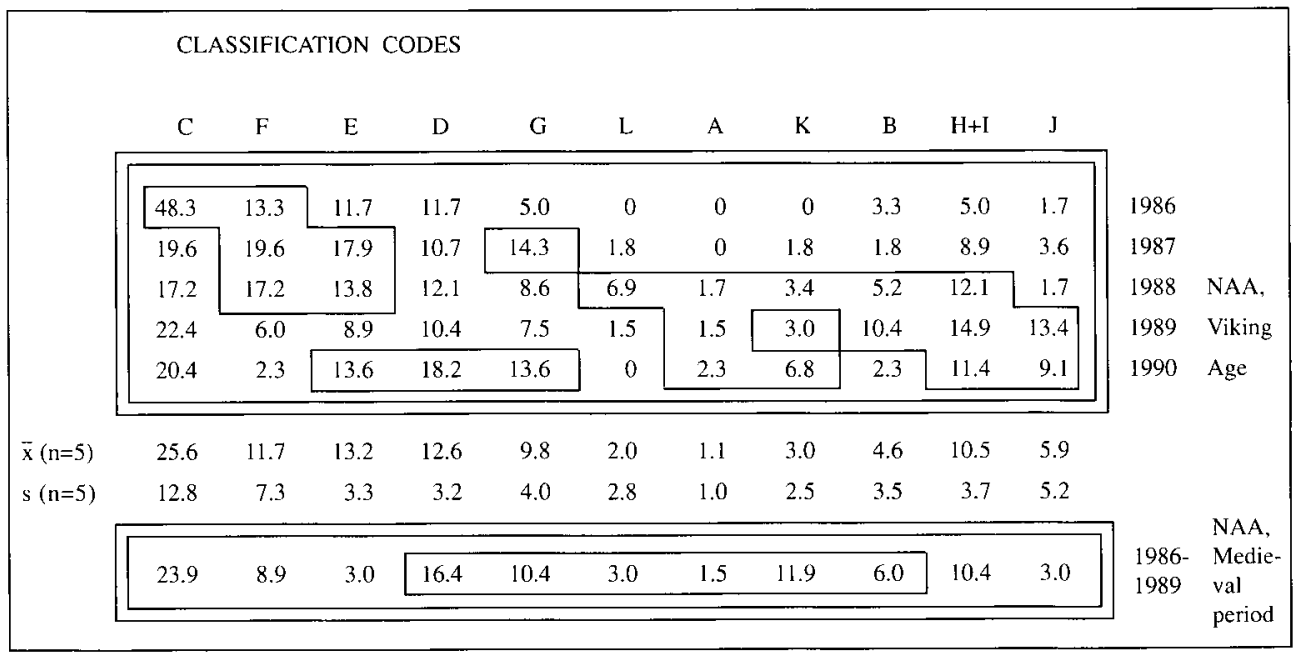

Tab. 2. Viking Age printed papers in the NAA 1986 - 1990. Seriation matrix as in Tab. 1.

altered and replaced by $8 \mathbf{J}$ in the first place, value $9.1 \%$ will rise to 11.1 , an exact adjustment in the matrix.

Another classificatory problem in this connection is associated with Anders Carlsson's monograph on penannular brooches from Gotland (NAA 1988:443). The aim of this work is to establish a chronology, but the work is not given the code $8 \mathrm{~B}$ but $8 \mathrm{~F}$ $8 \mathrm{H} 9 \mathrm{~F}$. This creates an under-representation for category $B$, visible in the matrix.

Comparing the two seriations shows that the doctoral theses belong to a rather conservative sphere, and that the fundamental tendency is not shown in the choice of subject but in the theory and method employed. This is a motive for the cyclic process which mainly relates to the subject. Compared with the doctoral theses, the NAA material for $1986-1990$ revealed a different picture but at the same time very remindful of the cyclic development illustrated. There is also stress on written sources in the NAA material. In the centre of the matrix for the NAA material the categories D - G - L together reflect the interest in rural settlement and sites in their social and natural context. This seems to be a turning point in the development. After the focus on rural settlement the urban settlement appears, after that the theoretical works, and in conclusion the works on paganism and Christianity, etc. The series can be said to commence with the artefacts and to conclude with the burials. Like the doctoral theses, the theoretical works are positioned rather late in the series.

There is heavy stress on category $\mathrm{C}$ for 1986. This might be explained by the publications of Vita Anskarii and Gesta Hammaburgensis (see below and NAA 1986:342, 366). The likewise observed over-representation for category J for 1989 might be explained by the investigations in Birka, Trelleborg in Sweden, and Bulverket (see below). The increase of category $\mathrm{H}+\mathrm{I}$ in 1988 can also be given a special explanation. An important factor of the rising interest in the eschatological and religious matters can probably be found in the first Nordic interfacultative conference in Isegran in April 1984 (NAA 1986:85, 86, 87, 124, 132, 134, 196, 237, 240, 242, 243, 267, 365, 410, 828). A cause and an effect can also be found in the two seminars in 1988 and 1989 at the University of Lund, "Burial customs and data" 


\section{HISTORICAL, PHILOLOGICAL}

AND NUMISMATIC SOURCES

F ARTEFACT STUDIES. ART.

STYLES. DRESS CUSTOMS.

E COMMUNICATIONS. TRADE. TECHNOLOGY. SUPPLY OF RAW MATERIAL.

D CULTURAL, ADMINISTRATIVE AND SOCIAL STUDIES.

G RURAL SETTLEMENT. HUNTING, FISHING, GATHERING, AGRICULTURE.

L ENVIRONMENT. BOTANY, GEOLOGY, OSTEOLOGY, ZOOLOGY.

A GENERAL. HISTORY OF ARCHAEOLOGY. BIBLIOGRAPHIES. OBITUARIES. BIOGRAPHIES. MUSEOLOGY. ACCESSIONS. INVENTORIZATION. CONSERVATION OF MONUMENTS. ANNUAL REPORTS.

K URBAN SETTLEMENT.

B THEORY. METHODS. TERMINOLOGY. DOCUMENTATION. PHYSICAL, CHEMICAL ANALYSES. CONSERVATION OF OBJECTS. CHRONOLOGY.

H+I PAGANISM AND CHRISTANITY. FUNERARY PRACTICE. MONUMENTS. BUILDINGS (only Christianity)

J SECULAR ARCHITECTURE. FORTIFICATIONS.

Tab. 3. Illustration/interpretation of the sequence of subjects (NAA standards) according to the seriation matrix in Tab. 2.

and "Archaeology and religion", respectively (NAA 1988: 110; NAA 1989:51, 54, 62, 73, $175,177,180,282,286,312,434,455)$. All in all it is interesting to see how the NAA material gives the impression of being closer to a front line of research than the doctoral theses (analyzed in this manner, that is). According to the two seriation matrices presented above, the future research can be expected to deal with surveys of chronological periods in a new way, studies of the cultural landscape, of the written sources and economy etc., congruent with an interpolation of the "third wave" of development. Judging from the NAA seriation, only the future publications can be expected to belong to categories A - K - B - H + I in some years.

In NAA from 1986 - 1989 (information for 1990 not available here) there are a number of abstracts which are primarily given the code Medieval period, but secondarily also Viking Age (NAA1986:448, 461, 471, 
$494,547,555,557,650,652$; NAA 1987 : $496,600,517,532,545,546,558$ a; NAA $1988: 505,512,515,517,642,663$; NAA 1989:460, 473, 497, 500, 504, 519, 616, 626, $636,640,657,663$ ).

An examination of those papers and works shows that this group, in the border zone between archaeology and medieval archaeology, contains a great variety of subjects, which indicates that this is a vital and dynamic field of research. This group will be tested separately from the Viking Age material with the support of a seriation (see Tab.2). Two typical features can be seen. Category E, "rural settlement", is much under-representated, while category K, "urban settlement", shows a marked over-representation. Category C, "Historical sources" has a rather high percentage, which seems logical. The result of the comparison presented in Tab. 2. is corroborative: this field of research to a certain degree represents a progressive trend. Most probably this is due to the fruitful constellation of two disciplines, but it can also be read chronologically: this field of research will very likely increase in the near future. Already it represents future development (see Tab. 2). To this category belongs the important thesis by Stefan Brink on the formation of parishes (Brink 1990). One of the most valuable features of the work depends on the contextual approach to the, basically linguistic, analysis, which puts the place-names in their social, economical and historical setting.

\section{IN SEARCH OF TRENDS; FOUR "FESTSCHRIFTE"}

Another group of publications which can be of interest to examine regarding possible trends are the "Festschrifte." Because of the special social as well as psychological circumstances for the rather arbitrary habit of dedicating such a publication to a teacher or colleague held in esteem, this group is supposed to offer a golden opportunity in this connection. During the time period there has appeared almost one "Festschrift" per year: (The publication for Erik Cinthio is left out.) In honorem Evert Baudou was published in 1985 (Baudou 1985:NAA $1985: 9,28,55,62,82,113,119,146,151$, $176,180,187,192,232,270,272,293,314$, $325,326,372,378,417,457,467,472,475$, $486,505,526,528,530,689,715,875,880$, $884,896)$.

Theoretical Approaches to Artefacts, Settlement and Society for Mats P. Malmer was published in 1987. (Malmer 1987:NAA $1987: 9,10,22,32,40,47,48,52,56,58$, $61,73,101,118,146,147,158,172,174$, $176,182,189,192,208,211,212,234,318$, $386,394,406,412,429,570,620,648,668$, 684).

Trade and Exchange for Berta Stjernquist from 1988 must also be left out on account of the special theme.

Mänsklighet genom millennier for Åke Hyenstrand was published in 1989 (Hyenstrand 1989; NAA 1989:19, 27, 49, 60, 61, $68,74,128,162,173,201,358,373,414$, $417,421,429,484,497,516,592,599,695$, $767,790)$.

Regions and Reflections, in honour of Märta Strömberg, was published in 1991 (Strömberg 1991; not yet in the NAA).

For each paper in these publications only the primary code will be used, and only the Viking Age period. The seriation matrix has been constructed in the same manner as earlier, but in this case the potential of the sources is smaller from the quantitative point of view because of the low frequencies. Nevertheless there is a tendency to be read (see Tab. 4.). When superimposed on the matrix in Tab. 3., both the concordance and the differences become clear. In general the matrices are congruent, but there are certain over-representations in Tab. 4. to be noted, especially in categories $\mathrm{G}$ and $\mathrm{L}$, and $\mathrm{H}+\mathrm{I}$, $\mathrm{J}$ in Baudou 1985 and Malmer 1987. This is due to small figures. Here, single papers have a strong impact of "supernatural" 
character. On the other hand, there is a covariation with Hyenstrand 1989 and Strömberg 1991 in the same categories. So this phenomenon can't be totally rejected as bias. A way of synchronizing the two matrices, Tab. 2. and 4., in a free way is to put them together and search for the "best fit." This is when the row for Hyenstrand 1989 is put over the row for NAA 1990 , the bottom line. On the one hand this means that the matrices structurally fully synchronize, but on the other that there is a certain retardation regarding the years of publication. The "Festschrifte" seem to differ c. 1 - 3 years from the NAA issues. The absence of papers belonging to categories $\mathrm{H}+\mathrm{I}$ and $\mathrm{J}$ in Strömberg 1991 can consequently be interpreted chronologically, i. e. as the expression of some kind of retardation in relation to the alleged front line of research. Archaeologists can sometimes be suspected of bringing slightly older ideas to the editors of the "Festschrifte." And when the development within archaeology is so fast that it can be followed bibliographically from one year to another, a couple of years can be an old age for a manuscript.

\section{THE GREAT PROJECTS,}

\section{THE CLASSICAL OBJECTS.}

The tendency to revert to the sources has also involved a renewed interest in the classical archaeological problems, places and objects. In Denmark this can be illustrated by the investigations at Jellinge (NAA 1986: 378, 397 c, 398, 401: NAA 1987:320, 336; NAA 1988:422, 469; NAA 1989:369) or the new publication by Mette Iversen, Ulf Näsman and Jens Vellev on the great Mammen find (Jysk Arkaeologisk Selskabs Skrifter XXVIII; cf NAA 1986:340). The publication of Vedel's excavations in Bornholm, Baekkegård and Glasergård by Lars Jørgensen also belongs to this tradition (Arkaeologiske studier 8; NAA 1990:242). The Ribe excavations and subsequent publications have had great impact on the re- search on early urbanization (Ribe Excavations 1970 - 1976. Ed. by Mogens Bencard. Esbjerg, NAA 1981:268, 333, 407, NAA 1984:383, NAA 1990: 256).

In Sweden Birka is the foremost example. Through Greta Arwidsson the publications of Birka II:2 (NAA 1986:396) and Birka II:3 (1989; NAA 1989:395) concluded the original Birka publication started by Holger Arbman and Dagmar Selling, the first volume of which appeared in 1938 (Geijer 1938). In 1985 Wladyslaw Duczko published his thesis as volume V (NAA 1986:389). During this time Lena Holmquist-Olausson carried out her investigations in Birka (cf NAA 1987:389; NAA 1989:444; NAA 1990:252). In 1990 the Ambrosiani project started, which has produced publications since 1991. In the meantime a flow of Birka literature has been printed (NAA 1986:341, $366,379,389,396,400,427,833$ m; NAA 1987;319e; 319r, 363, 389, 407b, 412, 558a, $606 x$; NAA $1988: 392,393,413,427,434$, $441,445,508,533,670,644$; NAA 1989:331, $366,375 \mathrm{e}, 375 \mathrm{~g}, 397,414,444,446,640,797$; NAA 1990:235, 252, 331).

A first report on the Sigtuna investigations 1988 - 1990 was published in the volume Makt och människor i kungens Sigtuna. (cf. NAA 1989:640). The comprehensive volume, which has a semi-popular style, contains no less than 28 papers on different topics, with the preliminary results presented under six headings: The Background and Method, The Town and the Urban Estates, Cultural Contacts and Trade, Craftsmen in Sigtuna, Domestic and Display, and Spiritual Life and Beliefs. The contributors mostly belong to the younger generation, which is possible to read from the rather markedly contextual approach.

There have also been investigations in Old Uppsala, which will continue to engage an increasing number of archaeologists during the 1990s and onwards (cf NAA 1986: $629 ; 1989: 366)$. In 1989 volume 72:II in the corpus "Medeltidsstaden" was published, 


\begin{tabular}{|c|c|c|c|c|c|c|c|c|c|c|c|c|}
\hline \multicolumn{13}{|c|}{ CLASSIFICATION CODES } \\
\hline & $\mathrm{C}$ & $\mathrm{F}$ & $\mathrm{E}$ & $\mathrm{D}$ & $\mathrm{G}$ & $\mathrm{L}$ & $\mathrm{A}$ & K & $\mathrm{B}$ & $\mathrm{H}+\mathrm{I}$ & $\mathbf{J}$ & \\
\hline & 7.7 & 23.1 & 15.4 & 15.4 & 0 & 23.1 & 0 & 0 & 0 & 7.7 & 7.7 & Baudou 1985 \\
\hline & 0 & 12.5 & 12.5 & 0 & 50.0 & 12.5 & 0 & 0 & 0 & 12.5 & 0 & Malmer 1987 \\
\hline & 12.5 & 12.5 & 0 & 25.0 & 37.5 & 0 & 0 & 0 & 0 & 12.5 & 0 & Hyenstrand 1989 \\
\hline & 0 & 0 & 28.6 & 14.3 & 14.3 & 0 & 14.3 & 14.3 & 14.3 & 0 & 0 & Strömberg 1991 \\
\hline $\bar{x}(n=4)$ & 5.0 & 12.0 & 14.1 & 13.7 & 25.4 & 8.9 & 3.6 & 3.6 & 3.6 & 8.2 & 1.9 & \\
\hline
\end{tabular}

Tab. 4. Four" Festschrifte". Seriation matrix as in Tab. I. and 2.

Visby, The Town and the Hinterland (NAA 1989: 449), containing eight separate papers. To the classical archaeological grounds belongs also Stockholm. In 1987 a thesis in medieval archaeology was published by Anders Ödman (Ödman 1987; NAA 1987:559; NAA 1988:642). The work was the result of the archaeological investigations in the very centre of the town on Helgeandsholmen in 1978 - 1981. On the basis of more than one thousand dendrochronological samples a chronology could be established, which dated the first constructions to around c. 1000 1020 AD (cf NAA 1982:625).

To the classical ground - or bottom - can also be counted Bulverket at Tingstäde on Gotland. This was investigated by Johan Rönnby (NAA 1989:446, 636, cf 626; NAA 1990:291). A thesis will appear in 1995.

Perhaps the most amazing archaeological find from the period 1986 - 1990 is the ringfort in Trelleborg in Sweden, discovered and excavated by Bengt Jakobsson (NAA 1989: 441, cf 436; NAA 1990:325). Before his untimely death the Danish archaeologist Leif Christian Nielsen published some important works, including a study of Omgård (see NAA 1987:358) and in 1990 a comprehensive study of the Danish ring-fort of Trelleborg (NAA 1990:329). He presents an extensive discussion of the socio-economic and political context of the construction and the settlement.

\section{TWO COLLECTIVE WORKS}

In 1989 there appeared a publication called Approaches to Swedish Prehistory. A spectrum of problems and perspectives in contemporary research (BAR International series 500, ed. by Th B Larsson and $\mathrm{H}$ Lundmark) (NAA 1989:11, 13, 20, 46, 66, 70, 81, $82,89,100,122,138,202,203,206,221$, $242,318,339,724,738)$. The main aim of this work, according to the introduction, was to inform a wider archaeological public about the current research in Swedish archaeology. The publication consists of two parts, altogether 21 different papers. The bibliographical profile of this work can be read from NAA, expressed graphically in Tab. 5. It is evident that this highly qualitative work has only one paper explicitly devoted to the chronological period of the Viking Age, in this case a numismatical study. Among the chronological periods, period 1 "general" dominates. On the other hand, only five of 21 papers are classified as "theory and method etc." (category B). The ambitious publication consequently can't be used conventionally, because it puts stress on other factors outside the scope of this bibliographical study. The situation here is rather the same as for the doctoral theses, that is when the choice of subject is not also 
conditioning the method or the theoretical direction. In fact, this is a measure of independence. The ruling mechanisms of scientific traditions are tenacious. Approaches to Swedish Prehistory has succeeded in being innovative, but is therefore not in general a good representative.

In the same year, 1989, another double volume was published in the periodical "Fornvårdaren 24" from the county museum of Östersund: Arkeologi i fjäll, skog och bygd. Del 2. Järnålder-medeltid (NAA 1989:773,774). Here only this second part will be discussed. It consists of 15 papers written by 10 different authors. Already a hasty glance reveals very high ambitions. This is strongly confirmed by a quantitative overlook. The absolute figures as well as the percentages are presented below.

\begin{tabular}{|c|c|c|c|c|c|c|c|c|c|c|}
\hline $\mathrm{C}$ & $\mathrm{F}$ & $\mathrm{E}$ & $\mathrm{D}$ & $\mathrm{G}$ & $\mathrm{L}$ & $\mathrm{A}$ & $\mathrm{K}$ & $\mathrm{B}$ & $\mathrm{H}+\mathrm{I}$ & $\mathrm{J}$ \\
\hline 0 & 2 & 1 & 1 & 6 & 2 & 0 & 0 & 2 & 7 & 1 \\
\hline 0 & 9.1 & 4.5 & 4.5 & 27.3 & 9.1 & 0 & 0 & 9.1 & 31.8 & 4.5 \\
\hline
\end{tabular}

Compared to the seriations above, this indicates a progressive approach. The row of percentages fits well after the last years of those matrices, 1990 and 1991 respectively. This could be read as a tendency "to be ahead." A methodological test will be performed here on this material in comparison with the matrices Tab. 4 and 5. The question is, to what extent do the rows correlate? The ideal formula when dealing with a numerical source of rather confined qualities as this one, is the rank correlation according to Spearman. The absolute figures (or percentages) are replaced by ranks. The highest figure is rank 1 and so on. The rank correlation here has a low discriminating effect as there are a number of so-called ties, i e when two or more observations share the same rank. This produces a limitation of the range of coefficients. To elucidate the results they are presented graphically in Tab. 6.

The existence of the chronological sequence gives strength to the result and the interpretation. The correlation with the "Festschrifte" is conspicuously stronger, with the exception of Strömberg 1991. Rather the same effect is also visible in comparison with the NAA issue for 1990. Those two consequently seem to be out of it. The rank correlation of the AIFSB, the work presented here, compared with the different issues of NAA forms a logical curve with the peaks on issues 1987 and 1988, which is in congruence with the "Festschrifte" where stress is put on 1987 and 1989.

This means that it is bibliographically possible with this quantitative method to follow the development within archaeology from one year to another. The strong correlation with some of the "Festschrifte" is a high mark for a publication from outside the university.

\section{COMMENTS ON CATEGORIES}

NAA: A, B, C, D, E \& G

The archaeological yearbook of the Central Board of National Antiquities and the National Museums, Arkeologi $i$ Sverige, has not been consistently included in NAA. During the time period the following volumes were published:

Arkeologi i Sverige 1984 (1986)

Arkeologi i Sverige 1985 (1987; NAA 1987: 
594)

Arkeologi i Sverige 1986 (1989)

Arkeologi i Sverige 1987 (1990)

From this voulme on, the serial numbers were changed. The subsequent volume was Arkeologi i Sverige, ny följd 1 (1991) and the following Arkeologi i Sverige, ny följd 2 (1993). The periodical presents information on the landscape and its ancient monuments as well as presentations of scientific results. The volumes contain a register, a catalogue of all archaeological investigations in Sweden. Arkeologi i Sverige is consequently an indispensable source of information on current archaeological activities.

A paper on the Viking Age can be found in volume 1984 (publ. 1986) on the Rösaring complex, by David Damell and Kerstin Östmark (pp 179-212). The excavations revealed, among other things, a c. $540 \mathrm{~m}$ long road connected to a big burial mound and the remains of a building.

Among the papers on the Viking Age in volume 1985 (publ. 1987) is an introductory article by Carolina Andersson and Marianne Summanen (Foghammar) on the village site of Gredelby in Knivsta parish (pp 7-28). The paper touches upon the intricate problems of spatial and chronological (and social) continuity from the Viking Age to the Middle Ages in the rural settlements. Archaeological remains of bloomery iron production are presented and discussed by LarsErik Englund (pp. 67-89). A paper by Malin Lindqvist, "Archaeology in Gotland from 1826 to 1985 ", contains information on Viking Age burials (pp. 91-100).

In the 1986 volume of Arkeologi i Sverige (publ 1989) there is a paper on Viking Age problems titled "On the track of the Viking Age farmer," by Kristina Lamm and Catharina Nilsson (pp. 265 ff).

A new periodical, Laborativ arkeologi, was introduced in 1986. The second volume was published in 1987, the third in 1988, the fourth in 1990, the fifth in 1991 and the sixth in 1992. Papers on Viking Age subjects appear in the first volume (NAA:347, 341), in the second volume (NAA 1987:389), in the third volume (NAA 1988:353, 403, 444) and in the fourth volume (a report on the excavations in the so-called Ormknös cemetery by Birgit Arrhenius). Volumes 5 and 6 are not commented on here, since they were

\begin{tabular}{|c|c|c|c|c|c|c|c|c|c|c|c|}
\hline & $\mathrm{C}$ & $\mathrm{F}$ & $\mathrm{E}$ & $\mathrm{D}$ & $\mathrm{G}$ & $\mathrm{L}$ & $\mathrm{A}$ & $\mathrm{K}$ & $\mathrm{B}$ & $\mathrm{H} / \mathrm{I}$ & $\mathrm{J}$ \\
\hline 1 & & & 1 & 1 & & $\mathrm{l}$ & 3 & & 3 & & \\
\hline 2 & & & 1 & & & & & & & 1 & \\
\hline 3 & & & & 1 & & & & & & & \\
\hline 4 & & 1 & & 2 & & & & & & & \\
\hline 5 & & & & 1 & & & & & & & \\
\hline 6 & & & & & & & & & 1 & & \\
\hline 7 & & & & & & & & & & 1 & \\
\hline 8 & 1 & & & & & & & & & & \\
\hline 11 & & & & & & & 1 & & 1 & & \\
\hline
\end{tabular}

Tab. 5. Diagram showing the bibliographical structure of the publication Approaches to Swedish Prehistory presented in the text. 
published after 1990 .

The papers concern a study of the incised grooves of runic inscriptions by Henry Freij (NAA 1986:437); a study of bronze-covered iron weights by Erik Sperber (NAA 1986: 341 ); a study of the agrarian settlement on Björkö by Lena Homquist-Olausson (NAA 1987:389); a preliminary report from the excavations in 1987 in the rampart of Birka by Lena Holmquist-Olausson (NAA 1989: 444); a study of the 150 weights found at Bandlunde on Gotland by Erik Sperber (NAA 1989:353); a study of the wooden textile-tools from the settlement at Elisenhof by Gertrud Grenander-Nyberg (NAA 1989: 403); and the above mentioned report on archaeological excavations. To summarize, the periodical Laborativ arkeologi has much relevance also for Viking Age research.

A good example of the development of archaeology in Sweden - from c. 1970/75 onwards a tendency to revert to the artefacts with new aims, methods and theories is the monographical study on the Gotlandic penannular brooches by Anders Carlsson (1988; NAA 1988:443). The work has been commented on above.

The category NAA:C, "historical, philological and numismatical sources", had two major contributions during the late 1980s, the Gesta Hammaburgensis by Adam of Bremen and the Vita Ansgarii by Rimbert, both in the form of new translations, by Emanuel Svenberg and Eva Odelman respectively, and with a scientific commentary (Gesta Hammaburgensis 1984; NAA 1986: 342 and Vita Ansgarii 1986; NAA 1986: 366 ). These two publications have contributed to a renewal of the scientific debate on early state formation, urbanization, the conversion to Christianity, as well as the early missionaries. (NAA 1986:353; NAA 1987:328; NAA 1988:410 and Nyberg in the NAA 1984; Cf Sawyer 1989 below, pp 16 - 17 and footnote 77; Gahrn1988 below, pp 72 ff and footnote 30; cf NAA 1989:484).

Both as a cause and an effect of the above two publications there has been a distinct focus on the Christianization and early mission, especially illustrated by the publication The Christianization of Scandinavia, edited by Birgit Sawyer et al, 1987 (NAA 1987:407), but also by the Krapperup symposium published in 1989 (NAA 1989: 372, 397, 447, 448; see also below) and a paper on the subject by Peter Sawyer in 1986 (NAA 1986:370). Under the heading "Christianity, conversion and mission" in NAA there are four titles listed for 1986, twelve titles listed for 1987, two titles for 1988 , eleven titles for 1989 and three titles for 1990.

A written source of the utmost importance to Viking Age research is the runic inscriptions. A new periodical, Runrön. Runological contributions, was introduced in 1989 (NAA 1989:333). In the first volume the research project "The Chronology of Viking Age Runic Inscriptions" is presented. The second volume by Lena Peterson from the same year presents a complete register of the words of the Swedish runic inscriptions, a corpus most valuble for any research. Volume 3 from 1990 contains the thesis by Henrik Williams titled "The osrune. Use and phonetic value in Rune-Swedish inscriptions on stone." Volume 4 from the same year contains the thesis by Svante Lagman titled "The Dotted Runes. Use and phonetic values in Rune-Swedish inscriptions."

The research project "Relations of Inheritance and Ownership in the Early Middle Ages," led by Birgit Sawyer, had a number of papers published during the period (NAA 1986:369; NAA 1988:409; NAA 1989: 640; NAA 1990:279).

Important archaeological research on the runic inscriptions has also been done by Anne-Sofie Gräslund (NAA 1987:405; NAA 1989:435). Most of the papers are presented in the periodical TOR (for the period after 1990, see no. 23:113 ff and no. 24:177 ff).

In 1987 the report was published from 


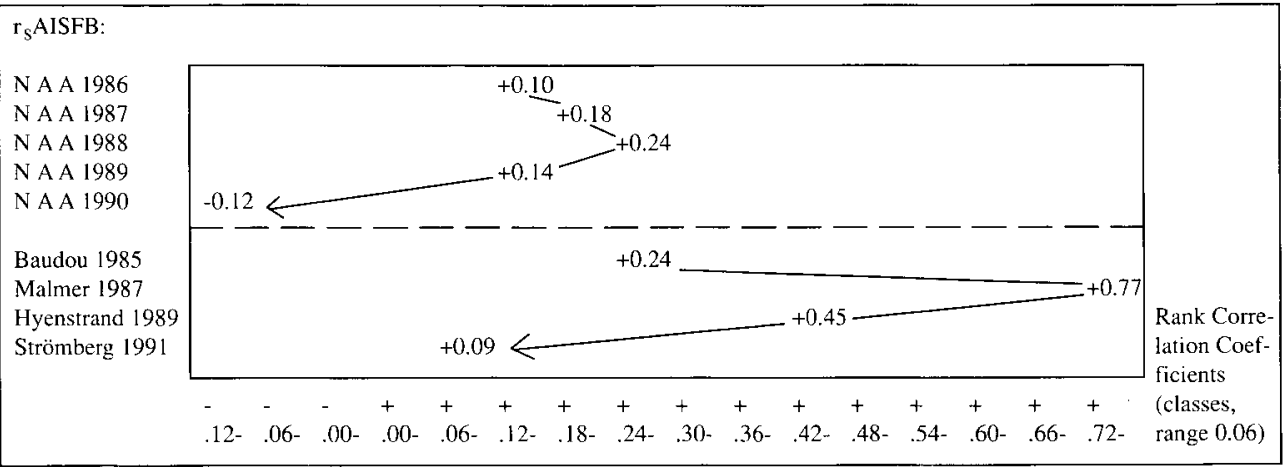

Tab. 6. Illustration of a rank correlation calculation (Spearman's formula) between the publication "Arkeologi ifjäll, skog och bygd" presented in the text, and the issues of the NAA and the four "Festschrifte".

the conference on Runes and Runic Inscriptions in September 1985 (NAA 1987:621). Apart from the basic linguistics there appeared papers on place-names, on the semantics of some titles, and on the spatial and social context, and so on (NAA 1987:62la, $621 \mathrm{i}, 621 \mathrm{k}, 621 \mathrm{t}, 621 \mathrm{v}$ ). A runological and archaeological contribution of importance is the article by Klas-Göran Selinge and Helmer Gustavson in the periodical Namn och Bygd 76 (NAA 1988:402). The authors apply the same method for typological analysis as was first successfully put into practice by Kerstin Kyhlberg (1983; NAA 1983:585 t): for instance, variables like the dimensions of the runic symbols, the number of runes, the height and width of the inscription, and so on. Another archaeologist to be mentioned is Mats G. Larsson, whose main research object is the runic inscriptions telling of Ingvar's expedition (NAA 1986:359; NAA 1990:290; cf NAA 1990:340). The research of Mats G. Larsson stands firmly on the basis of settlement archaeology as well as qualitative aspects.

The numismatic field is enormous. Even the editors of NAA recommend the readers to consult the numismatic literature for better coverage. Here only some brief comments will be made. The Commentationes de Nummis Saeculorum IX - XI in Suecia Repertis. Nova Series, with Brita Malmer as editor, was introduced in 1987 (Jonsson 1987, not included in NAA). Hitherto volumes 1, 2, 4 and 6 have been published (NAA 1989:335, 346; NAA 1990:261; Beside this series, the Corpus - series is continuously published). For Viking Age research, volume 2 on Byzantine coins, volume 4 on the Sigtuna coinage c. 995-1005, and volume 6, "Sigtuna Papers. Proceedings of the Sigtuna Symposium on Viking-Age Coinage 1-4 June 1989" are of special interest. Papers on statistical and metrological questions have been presented by Frands Herschend (NAA 1987:354; NAA 1989: 339, 739) and Sven Brahme (NAA 1990: 264).

Also of special interest to Viking Age research is the ongoing "The Gotland Hoard Project," started in 1977 by Majvor Östergren and pursued in numismatic collaboration with Kenneth Jonsson. During the period 1986-1990 a number of papers presenting different results or problems have appeared (NAA 1986:356, 708i, 708k, 798j; NAA 1988:95, 394, 404; NAA 1989:248, 380; NAA 1990:261j). Many papers have appeared in the periodical Gotländskt arkiv, edited by the county museum on Gotland. 
Leaving category $\mathrm{C}$ for category NAA: $\mathrm{D}$, "cultural, administrative and social studies", there is a connection with research on the written sources. The main features of Viking Age research are the formation of the state, urbanization, and the social strata of the society in general.

Excavations of some major estates/farms have given very important information, such as Signhildsberg (NAA 1989:640 d), Granby (NAA 1989:417) and other places (cf NAA 1987:385, 386). The investigations of the royal estate on Adelsö in the vicinity of Birka will be published in the late 1990s.

In 1988 and 1989 four different works appeared, all of them important contributions to the research on the formation process of the early Swedish state. They were written by three historians and one archaeologist, all four belongning to different academic traditions: Lars Gahrn 1988 (not in NAA), Thomas Lindkvist on predatory incursions, royal taxation and the formation of a feudal state (NAA 1988:517), Peter Sawyer's The Making of Sweden (NAA 1989:504) and Åke Hyenstrand's Sweden in 989 (NAA 1989:366).

From the scientific perspective of medieval archaeology, there were a number of contributions to this topic in the Krapperup publication, The Birth of the Middle Ages, by Ole Fenger, Åke Hyenstrand, Thomas Lindkvist and Klavs Randsborg (NAA 1989:52, 365, 500, 750).

The traditional field of research, settlement archaeology, got a contribution also associated with the subject above, namely Anders Broberg's 1990 thesis Farmers and Society at the Time of State Formation. A Settlement Archaeological Study of the Barknare-projektet III (NAA 1990:286). Compared with the pioneer work by Björn Ambrosiani from 1964, the thesis by Broberg can be said to be more or less "multivariate." The perspective is no longer primarily the single farmstead or the local district, but the northern parts of the pro- vince of Uppland and their colonisation during the Viking Age from an inter-regional point of view.

To the category NAA:E, "technology, supply of raw material etc.", belongs the thesis by Gert Magnusson on bloomery iron production in the province of Jämtland (NAA 1986:81). This work can be considered a pioneer achievement in its field of research. The furnaces are classified typologically and technically; and local and regional series of $\mathrm{C} 14$ dates allow for an extensive chronology of the Iron Age in northern Sweden and the activities connected with iron production. Later, in 1989, the thesis by Pär Hansson was published, which also deals with the question of the importance of iron production, for the society of Närke, during the Iron Age and the Middle Ages (NAA 1989:763).

In the category NAA:G, "rural settlement, etc.," special notice must be given to the thesis by Majvor Östergren mentioned above: Between Stone House Foundations and Stone Houses. The Viking Age Silver Hoards of Gotland as Indicators of Settlements (NAA 1989:420). The project was initiated as a means of securing archaeological information on the find circumstances of the Gotlandic silver hoards, as there had been a number of robberies with metal detectors. A major scientific instrument of the project was the metal detector, and in consequence a lot of artefacts other than coins were collected. The basic result of the project was the establishment of the fact that the silver hoards were originally deposited on the farms and in the houses. Consequently, the analysis of the thesis was conducted in a sphere connecting numismatics, settlement archaeology and artefact archaeology.

\section{CONCLUDING REMARKS}

The aim of the study was to try to analyze Swedish archaeology, especially the research published on the Viking Age during 
the period 1986-1990, on the basis of Nordic Archaeological Abstracts. The codification/indexations proved very useful to quantitative analyses as well. The accuracy made it possible to discern one year of publications from another with the help of seriation analysis. Research on the Viking Age in Sweden appears to develop and to change direction rather rapidly during the 1980s. There seems to be a major change around 1987-1988.

The long-term analysis shows that Swe-

\section{REFERENCES}

Almgren, O. 1897. Studien über nordeuropäischen Fibelformen der ersten nachchristlichen Jahrhunderte mit Berücksichtigung der provinzialrömischen und südrussischen Formen. 1 - 2. Stockholm.

Ambrosiani, B. 1964. Fornlämningar och bebyggelse. Studier $i$ Attundalands och Södertörns förhistoria. KVHAA monografier. Uppsala.

Approaches to Swedish Prehistory. A spectrum of problems and perspectives in contemporary research. 1989. BAR International series 500. Eds. Th. B. Larsson \& H. Lundmark.

Arkeologi i fjäll, skog och bygd. Del 2. Järnålder medeltid. 1989. Fornvårdaren 24. Östersund.

Arkeologi i Sverige 1985. Riksantikvarieämbetet och Statens Historiska Museer. Rapport 1987:1.

Arkeologi i Sverige 1986. Riksantikvarieämbetet och Statens Historiska Museer. Rapport 1988:2

Arkeologi i Sverige 1987. Riksantikvarieämbetet och Statens Historiska Museer. Rapport 1990:1

Arkeologi i Sverige. Ny följd 1. 1991. Riksantikvarieämbetet och Statens Historiska Museer.

Arkeologi i Sverige. Ny följd 2. 1993. Riksantikvarieämbetet och Statens Historiska Museer.

Arwidsson, G. 1942. Vendelstile, Email und Glas im 7. - 8. Jahrhundert. Valsgärdestudien I. Uppsala/Stockholm.

Baudou, E. 1985. In honorem Evert Baudou. Archaeology and Environment 4. Ed. by M Backe et al. Umeå.

Boken om Ansgar. Rimbert: Ansgars liv (Vita dish archaeology has undergone two separate and concluded "waves of traditions" during the twentieth Century. The current tradition had its beginning around 1970/75. The development describes a hermeneutic spiral which has its "roots" in the artefacts and the empiristic school of research. Modern research shows clear tendencies to focus on the contexts.

English revised by Laura Wrang.

Ansgarii). Övers. av Eva Odelman. 1986. Stockholm.

Braudel, F. 1980. On history. London.

Brink, S. 1990. Sockenbildning och sockennamn. Studier $i$ äldre territoriell indelning $i$ Norden. Studier till en svensk ortnamnsatlas 14. Acta Academiae Regiae Gustavi Adolphi 57. Uppsala.

Broberg, A. 1990. Bönder och samhälle i statsbildningstid. En bebyggelsearkeologisk studie av agrarsamhället $i$ Norra Roden $700-1300$. Rapporter från Barknåre-projektet 3. Upplands Fornminnesförenings tidskrift 52. Uppsala.

Carlsson,A. 1988. Vikingatida ringspännen frän Gotland. Text och katalog. Stockholm Studies in Archaeology 8. Stockholm.

Cleve, N. 1943. Skelettgravfälten på Kjuloholm i Kjulo. Del I. Den yngre folkvandringstiden. Finska Fornminnesföreningens Tidsskrift XLIV. Helsingfors.

Commentationes de Nummis Saeculorum IX - XI in Suecia Repertis. Nova Series. KVHAA. Stockholm.

Cullberg, K. Ekehögen-Backa Röd-Valtersberg. Studier i nordisk arkeologi 12. Göteborg.

Duczko, W. 1985. Birka V. The Filigree and Granulation Work of the Viking Period. KVHAA. Stockholm.

Ferenius, J. 1971. Vårby och Vårberg. En studie i järnålderns bebyggelsehistoria. Studies in North-European Archaeology. Series B. The- 
ses and papers published in offset.1. Stockholm.

Gabrielsson, R. 1945. Kompositionsformer i senkeltisk orneringsstil sedda mot bakgrunden av den senkeltiska konstutvecklingen. KVHAA Handlingar 58:2. Stockholm.

Gahrn, L. 1988. Sveariket i källor och historieskrivning. Meddelanden från Historiska Institutionen vid Göteborgs universitet, nr 36. Göteborg.

Geijer, A. 1938. Birka III. Die Textilfunde aus den Gräbern. KVHAA Stockholm.

Gesta Hammaburgensis Ecclesiae Pontificum. Adam av Bremen. Övers. av Emanuel Svenberg. 1984. Stockholm.

Hagberg, U. E. 1967. Skedemosse. Studier i ett öländskt offerfynd från järnåldern. KVHAA monografier. Stockholm.

Hansson, P. 1989. Samhälle och järn i Sverige underjärnåldernochäldremedeltiden.Exemplet Närke. Archaeological Studies. Uppsala universitet 13. Uppsala.

Holmqvist, W. 1939. Kunstprobleme derMerowingerzeit. KVHAA Handlingar 47. Stockholm.

Hougen, Bj. 1935. Snartemofunnene. Studier $i$ folkvandringstidens ornamentikk og tekstilhistorie. Norske Oldfunn 7.

Hyenstrand, Å. 1988. Om arkeologi - idag, igår och imorgon. Samhällsteori och källmaterial aktuell arkeologiII. Stockholm Archaeological Reports Nr 21. Stockholm.

-1989. Sverige 989. Makt och herravälde I. Stockholm Archaeological Reports 24. Stockholm.

Hägg, I. 1974. Kvinnodräkten i Birka. Livplaggens rekonstruktion på grundval av det arkeologiska materialet. Archaeological Studies. Uppsala universitet. 2. Uppsala.

Jensen, R. 1988. Anteckningar om postprocessuell arkeologi. Samhällsteori och källmaterial aktuell arkeologi II. Stockholm Archaeological Reports Nr 21. Stockholm.

Kroeber, A. L. 1919/1952. Order in Changes of Fashion. The Nature of Culture. Chicago.

Kyhlberg, K. 1983. Kvinnor och män $i$ uppländska runinskrifter - en metodstudie. Seminar paper. Stockholm.

Kyhlberg, O. 1982. Arkeologi i Norden under 1900talet. En bibliografisk analys av doktorsavhandlingarna från 1897 - . Arkeologiska rapporter och meddelanden från Institutionen för arkeologi vid Stockholms Universitet, $\mathrm{Nr} 12$. Stockholm.
Laborativ Arkeologi. Ed. Birgit Arrhenius (1, 1986;2,1987;3, 1988;4, 1990;5, 1991;6, 1992). Arkeologiska forskningslaboratoriet, Stockholms universitet.

Larsson, M. G. 1990. Runstenar och utlandsfärder. Aspekter på det senvikingatida samhället med utgångspunkt i de fasta fornlämningarna. Acta Archaeologica Lundensia. Series in $8^{\circ}$. No 18. Lund.

Lidén, O. 1938. Sydsvensk stenålder belyst av fornfynden på boplatserna i Jonstorp. I Skivyxkulturen. Lund

Lindkvist, T. 1988. Plundring, skatter och den feodala statens framväxt. Opuscula Historica Upsaliensis 1. Uppsala.

Lundström, A. 1971. Helgö-studier 1. Frågor kring handel, hantverk och samhälle. Studies in North-European Archaeology. Series B. Theses and papers published in offset. 2. Stockholm.

Magnusson, G. 1986. Lågteknisk järnhantering $i$ Jämtlands län. Jernkontorets bergshistoriska skriftserie 22. Stockholm.

Malmer, M. P. 1987. Theoretical Approaches to Artefacts, Settlement and Society. Studies in honour of Mats $P$ Malmer. Eds. G. Burenhult, Å. Hyenstrand, A. Carlsson \& T. Sjøvold. BAR International series 366 .

Marstrander, S. 1963. Østfolds jordbruksristninger. Skjeberg. Tekstbind. Plansjebind. Instituttet for sammenlignende kulturforskning. Serie B. Skrifter LIII. Oslo/Trondheim.

Medeltidensfödelse. Symposier på Krapperups borg 1. Ed. by A Andrén. Lund 1989.

Nordic Archaeological Abstracts 1986, 1987, 1988, 1989, 1990.

Oldeberg, A. 1933. Det nordiska bronsåldersspännets historia, med särskild hänsyn till dess gjuttekniska utformning $i$ Sverige. KVHAA Handlingar 38:3. Stockholm.

Runrön. Runologiska bidrag utgivna av Institutionen för nordiska språk vid Uppsala universitet (Vol. 1, 1989; Vol. 2, 1989; Vol. 3, 1990; Vol. 4, 1990; Vol. 5, 1992; Vol. 6, 1992; Vol. 7, 1992).

Sawyer, P. 1989. The Making of Sweden. Occasional Papers on Medieval Topics 3. Alingsås.

Steensberg, A. 1943. Ancient Harvesting Implements. A Study of Archaeology and Human Geography. Nationalmuseets Skrifter. Arkaeologisk-Historisk Raekke I. København.

Stenberger, M. 1933. Öland under äldre järn- 
åldern. En bebyggelsehistorisk undersökning. KVHAA Monografier. Stockholm.

Stjernquist, B. 1955. Simris. On Cultural Connections of Scania in the Roman Iron Age. Acta Archaeologica Lundensia. Series in 40. No 2. Lund.

Strömberg, M. 1991. Regions and Reflections. In honour of Märta Strömberg. Eds. K. Jennbert, L. Larsson, R. Petré \& B. Wyszomirska-
Werbart. Acta Archaeologica Lundensia. Series in 80 . No 20. Lund.

Ödman, A. 1987. Stockholms tre borgar. Från vikingatida spärrfäste till medeltida kastellborg. Stockholmsmonografier 80. Stockholm.

Östergren, M. 1989. Mellan stengrundoch stenhus. Gotlands vikingatida silverskatter som boplatsindikation. Theses and Papers in Archaeology. New series 2. Stockholm. 
